\title{
THE FIRST AMENDMENT IN A TIME THAT TRIES MEN'S SOULS
}

\author{
SUSAN GELLMAN*
}

These are the times that try men's souls. ${ }^{1}$

There is no freedom in a land where fear and hate prevail. Isn't this a time?

A time to try the soul of men,

Isn't this a terrible time?

Whether or not First Amendment rights are especially important during a crisis, they are nonetheless especially at risk then: Government requests to suspend civil liberties are always rationalized by "crisis." In the aftermath of the terrorist attacks of September 11, 2001, not only legal scholars, but all Americans, wondered what the civil liberties fallout would be. A particular area of concern was, and still is, the First Amendment protections, especially of speech and press. It seems, though, that the greatest threat to First Amendment liberties may come from unexpected sources.

Even before the calendar changed to September 12, civil libertarians right and left expressed concerns that the terrorist attacks might trigger a broad spectrum of restrictions upon individual liberties. The rights of travel and privacy came to mind at once. But it was not long afterward that people began to worry that censorship of speech and press would be imposed as part of a war effort. Loose lips sink ships, after all. Soon after came worries about restrictions of religious expression by Muslims and fears of governmental religious coercion, where patriotic sentiment could become conflated with religious symbols and expression. Commentators of all political stripes warned against panicky restrictions of speech and press rights, often pointing out the irony of restricting American freedoms in an effort to fight an enemy whose disdain for the United States rests in part upon those very freedoms.

And then a surprising thing happened: Nothing.

Well, not nothing, but significantly less, in the way of government infringement upon civil liberties, than many of us had feared in the dangerous early period. In the first few weeks after the September attacks, Congress gave a stinging rejection to Attorney General John Ashcroft's initial request for expanded

Copyright (C) 2002 by Susan Gellman

This article is also available at http://www.law.duke.edu/journals/65LCPGellman.

* The author is an attorney in private practice with the firm Wolman, Genshaft \& Gellman. She thanks for their valuable contributions Julia Davis, Esq., and her mother, Rosalie Gellman, Marquette University Law School, Class of 2002.

1. Thomas Paine, The American Crisis, Dec. 23, 1776.

2. Lee Hayes \& Walter Lowenfels, Wasn't That a Time? (Sanga Music, Inc. BMI 1948), available on Peter, Paul \& Mary, A Song WILl RiSE (Warners Bros., 1965). 
snooping and detention powers. Later, the Bush Administration and Congress would adopt dreadful "antiterrorism" measures, but at the beginning, the federal government was surprisingly restrained.

In fact, officials at all levels of government went out of their way to assure the public that the United States would not "hand a victory" to the terrorists by voluntarily restricting the very American freedoms that the terrorists presumably hate and resent. Far from establishing internment camps like those established for Japanese-Americans during World War II, the President immediately cautioned against discrimination against Arabs and Muslims. Nearly every time a public official made a statement in the first few days after the attacks, he or she seemed to feel compelled to add that "this is not a war against Muslims," and that "Islam does not condone violence"-the latter being proclaimed whether the speaker knew anything about Islam or not.

Ultimately, of course, there has been plenty to alarm civil libertarians. At the end of October, the Bush Administration quietly erected obstacles to young men immigrating to the U.S. from Arab countries and established new rules making it chillingly easy for government officials to eavesdrop on communications between people suspected of crimes and their attorneys. Revised procedures for detention, interrogation, and trial by secret military tribunals with no right of appeal, and other outrages, followed-although the first charges, brought against Zacarias Moussaoui, the suspected "twentieth terrorist," were actually brought in a regular civilian federal district court. And much more is likely to come in the way of government infringement upon our rights to privacy, counsel, due process of law, and equal protection, as guaranteed by the Fourth, Fifth, Sixth, and Fourteenth Amendments, both through official suspension of legal safeguards or simple disregard of them by police.

But at least as of this writing, ${ }^{3}$ it truly cannot be said that government in the United States has responded to the current crisis by grossly restricting our First Amendment rights of speech, press, or religion. That is not to say, however, that those freedoms are not in danger arising out of the crisis.

Government censorship and repression is not the only threat to the freedoms listed in the First Amendment. Think for a moment about what all those freedoms are about: protection of the one who disagrees with the majority, or who is different in some matter of ideology or belief. The Bill of Rights in general, the First Amendment in particular, acts as a safety valve on a majorityrules democracy. The tyranny of the majority can be every bit as oppressive as the tyranny of a monarch-perhaps even more so, as there is no sense of noblesse oblige, but instead the assumed sense of fairness and legitimacy that comes with the right to vote. Thus the First Amendment exists, like a miniEqual Protection Clause, to protect minorities-even minorities of one-from

3. There is always a risk involved in writing about contemporaneous events, still unfolding at the time of publication. Undoubtedly events between the time of writing and the time of publication, let alone the time of reading, will render much if not all of this essay obsolete or even altogether wrong and certainly foolish. Such are the risks of freedom of speech. 
losing every time (even "fair and square" by majority vote). And it works admirably well.

But when it comes to forcing conformity of belief and behavior, government coercion takes a back seat to private, social pressure. Even government's most powerfully threatening tool, criminal prosecution, is less effective at thought and speech control than the power of society. In matters of opinion, whether by fashion or persuasion, we tend to believe what others around us believe, not what the government tries to force us to believe. A law requiring the recitation of the Pledge of Allegiance or compulsory draft registration will mean that more people recite the pledge or register for military service, but it won't be because the threat of punishment made them feel more patriotic. Perhaps you wore a flag pin or a red, white, and blue ribbon after September 11. If you did, it was probably because you saw other people wearing them, and the gesture appealed to you-not because some government official "suggested" that you express your loyalty. Maybe you flew an American flag from your home or car-because you wanted to do it. Your friends and neighbors were flying their flags, and it seems like a good, patriotic idea. Now imagine how you would feel if there were a law requiring you to display a loyalty emblem on your person or home. If the government made flag display compulsory, many of those now displaying flags voluntarily would take them down in protest, and most of the rest would resent the coercion to do exactly what they loved doing voluntarily. People in government know this, and that's why we haven't seen (and probably won't see) even ardent supporters of an anti-flag-burning amendment calling for compulsory flag displays.

It's not just that we are a society that loves and is accustomed to expecting liberty. Social pressure is a very powerful means, more effective than government persuasion and even the threat of criminal prosecution, of getting people to think and behave in a certain way, whether we are talking about generally accepted positives such as civility and tolerance or the less desirable ends of conformity and political correctness, let alone bigotry and xenophobia.

And this is particularly true in times that try our souls. When we feel a sense of threat and crisis, we feel an instinctive urge toward unity-closing the ranks, circling the wagons-lest divided we fall. This urge brings out some of the best in us: Witness the countless reports of heroism, neighborliness, and generosity following the September attacks. Many people have applauded the "reclaiming" of the flag as a widely shared symbol of love of country by the liberal and moderate members of a generation for whom, ever since the 1960s, it has been freighted with Vietnam-era militarism and has been seen as the symbol of only a politically conservative kind of patriotism.

But the impulse toward unity can bring out some scary things, too. Even in peacetime there is pressure to conform to positions and ideas seen by their adherents as pro-social and important, in the name of the greater good. Boosterism during times of economic growth makes skeptics feel that they, too, should display enthusiasm and bite their tongues on their doubts, rather than shake 
consumer confidence. Conservative academics have long complained that they feel that their voices are stifled at schools they consider liberal, not by official university policies, but by the condemnatory pressure of their politically correct peers. In time of crisis, though, the whole scale is ratcheted up several notches as the impulse toward unity becomes urgent. It no longer simply seems desirable that we all agree; it feels like unity is crucial to our safety and survival.

The tyranny of the majority makes itself felt through official action of a majoritarian government, but it also operates quite effectively through the more elusive forces of social pressure. The Bill of Rights is our bulwark against official enforcement of majority opinion. But there is nothing in the Constitution to protect us from the more powerful private social compulsion.

Thus, the distinction between governmental control and private social pressure has always been the starting point of legal analysis. The threshold concern of constitutional law is government action; without it, there is no constitutional issue. ${ }^{4}$ So for the purpose of legal analysis, the distinction is crucial. But for examining actual effects on the liberties protected by the First Amendment, that may not be true. When one has an unpopular idea to express, how different from government censorship, in actual silencing effect, is the fear of social condemnation? In a democracy, the line between government oppression and social coercion may be fine indeed, and the danger to liberty, including First Amendment liberties, is no less pernicious from the latter than from the former.

All this does not mean that it is therefore permissible, or even desirable, for government to have the power to interfere with private action that is itself an exercise of free speech, even when that private action leads to pretty much the same result that the First Amendment forbids where there is state action. We would sell our freedom to our own thoughts and actions far too cheaply if we agreed, "for the greater good," to grant the government the power, say, to define, prohibit, and punish hate speech. That is exactly what we would be doing if we tried to avoid the private social effect of tyranny of the majority by granting the government the power to prohibit social coercion.

Rather, We The People must exercise restraint ourselves, without government compulsion. That is not to say "without government participation," however-the government is itself a speaker in the public debate, and just as our government leaders have the right to try to persuade us, for example, of the correctness of its policy in Afghanistan, they also have the responsibility to encourage the public not to infringe upon one another's exercise of civil liberties. But we need to have the will and the energy to protect and respect First Amendment values ourselves, without taking the misstep of authorizing our representative government to do it for us.

4. The Thirteenth Amendment, abolishing private slavery, and the Eighteenth and Twenty-First Amendments, imposing and repealing prohibition of private alcohol sales, may be considered exceptions, but in general the Constitution is concerned solely with the relationship of government to itself and to the people, not with relationships between private parties. 
I

\section{ARE WE OUR OWN WORST ENEMY?}

\section{A. Threats to a Free Press}

At least so far as we know, government so far has been remarkably restrained in imposing any kind of censorship upon the print media, television, radio stations, Internet sites, and publishers. In September 2001, the State Department asked the United States government-funded Voice of America radio network ("V.O.A.") not to run a previously recorded interview with Taliban leader Mullah Mohammad Omar, citing the risk that the broadcast could be used by terrorists to communicate messages; the State Department also added that the interview was not "newsworthy" anyway. But when V.O.A. employees protested, the State Department backed down, and V.O.A. aired the interview later that month.

The closest the government has come so far to censorship of privately owned media has been National Security Advisor Condoleezza Rice's request in mid-October that television networks use caution when broadcasting speeches by Osama bin Laden. White House Press Secretary Ari Fleischer explained that the Administration feared that "[a]t best, Osama bin Laden's messages are propaganda calling on people to kill Americans. At worst, he could be issuing orders to his followers to initiate such attacks."

Now, a request from the government is a powerful thing. But it isn't censorship - neither legally, nor in actual effect. The networks didn't cave. Although most networks thereafter issued only modified, as opposed to full and verbatim, coverage of Osama bin Laden's speeches, they did offer reports on those speeches. To the extent they restrained themselves, it probably had nothing to do with fear of government retaliation, deference to the Administration's request, or patriotism and wartime caution at all for that matter. It most likely had everything to do with their ratings. Most networks would cringe at devoting valuable air time to long, rambling speeches in Arabic by either friend or foe, even if the President asked them to do it. After all, only one of the four major television networks even broadcast President Bush's own address on November 8-at prime time, right in the middle of "sweeps week." In December, when the Administration wanted broadcast of the "smoking gun" videotape in which Osama bin Laden apparently acknowledged that he was behind the Sep-

5. James Warren, Reporter Off Radio After Taliban Story, CHI. TRIB., Feb. 6, 2002, at 3. Unfortunately, the reporter who got the interview was later "taken off the air and reassigned to what she and the agency's news director call a 'useless job." Id.

6. Tim Jones \& Bob Kemper, TV Pressed on bin Laden Tapes, CHI. TRIB., Oct. 11, 2001, at 1. It would seem that, even if the major networks did not carry the speech, anyone who wanted to hear the whole thing could probably find it easily on the Internet. For the sake of argument, and in deference to facts we do not know, we will assume that there is some potential security value in excluding full speeches from network television.

7. Lisa de Moraes, Networks Decide Bush's Speech Doesn't Rate, WASH. Post, Nov. 9, 2001, at C1. 
tember attacks, the Administration was surely glad that it had restrained itself in October.

Unfortunately, the government's restraint from censorship has not meant that the American public is left with a free, independent, and unbiased press delivering news at this critical time. The limitation upon crucially needed, unbiased news reporting has come from private sources, sometimes including the news media outlets themselves.

The first widely publicized incident of this self- or pseudo-censorship was the outcry following a comment made by Bill Maher on his discussion-oriented, satirical news show, Politically Incorrect. ${ }^{8}$ Maher did not express support for the terrorists or excuse their actions, but he did suggest that the oft-repeated labeling of the terrorists who hijacked and destroyed the planes on September 11, who killed themselves along with their victims in the process, as "cowards" was not particularly apt, and might even apply better to people dropping bombs upon distant targets, obviously alluding to an American counter-attack. There was a public outcry, accusing Maher of attacking the United States military and supporting the terrorists, followed quickly by major advertisers pulling their sponsorship of Politically Incorrect and several local stations dropping the show.' The accusation of being unpatriotic probably hurt Maher more than censorship by the government would have done.

Some news outlets have gone even further in stifling dissent. A columnist for the Grant Pass, Oregon Daily Courier and the city editor for the Texas City Sun were both fired by their papers after criticizing President Bush for not returning promptly to Washington or being more visible immediately after the September 11 attacks. ${ }^{10}$ The National Review dropped conservative commentator Ann Coulter's syndicated column from its website after she advocated "in$\operatorname{vad}[i n g]$ their [terrorists'] countries, kill[ing] their leaders, and convert[ing] them to Christianity." "When she complained, she was fired from her post as contributing editor. ${ }^{12}$ A student-run newspaper at the University of California at Berkeley ran a syndicated cartoon showing two Muslims, evidently terrorists, entering hell and celebrating their arrival in paradise. Student protesters held a sit-in at the paper's office and gave the editors a list of demands, including a front-page apology. When the newspaper refused, the student senate-not the university administration, but other students-cut off the paper's funding and ordered its staff to attend mandatory sensitivity training. ${ }^{13}$

8. Politically Incorrect (ABC Television 2001).

9. Bill Carter \& Felicity Barringer, Speech and Expression; In Patriotic Time, Dissent is Muted, N.Y. TIMES, Sept. 28, 2001, at A1.

10. Robert P. Laurence, Gag Reflex: We've Met the Enemy, and It is Us, SAN DIEGO TRIB., Oct. 2, 2001, at E1.

11. Howard Kurtz, National Review Cans Columnist Ann Coulter, WASH. Post, Oct. 2, 2001, at C1.

12. $I d$.

13. Debra J. Saunders, Editorial, University of Censorship's Fall Semester, S.F. CHRON., Oct. 1, 2001, at A25. 
This private "censorship" isn't unprecedented. There have long been protests against television shows felt to be condoning homosexuality or promiscuity, for example, and boycotts of their sponsors. But even when the pressure was successful, what it stifled was entertainment shows. While there is still an actual infringement, albeit not unconstitutional government censorship, of freedom of speech from the bullying of entertainment providers by private individuals and organizations, it does not interfere with the public's right to be informed on important news issues in the way that pressure, internal as well as external, upon news outlets does.

And some news outlets frankly admit that they have a point of view the promotion of which is more important to them than a reputation for unbiased reporting. Brit Hume, a news anchor for the Fox News Channel, said, "Look, neutrality as a general principle is an appropriate concept for journalists who are covering institutions of some comparable quality .... This is a conflict between the United States and murdering barbarians." ${ }^{14}$ Of course, this is presumably exactly what the attackers would say, simply reversing the roles. And if the case for calling an enemy a "murdering barbarian" is so clear, it ought to be enough to present the facts in an unbiased manner and let the audience arrive at that conclusion themselves, without the news source sacrificing its reputation for objectivity. If it somehow is objective to call someone "evil," then it is also unnecessary.

The gesture of wearing a little flag pin on one's lapel meant a lot to the people wearing them, and probably also to many others who saw them and were cheered by the feeling of solidarity. To some people, the symbol expressed support for the Administration or for the war effort; to others, it meant simply general patriotic sentiment and solidarity. When television news reporters began to wear flags and tri-color ribbons, though, many viewers were troubled by the appearance of bias in reporting. Were their news outlets still objective sources of the whole story? A local station in Columbus, Ohio ran promotion spots featuring its news team announcing, "We want you to know we stand 100 percent behind the President"-leaving viewers to wonder exactly what that might mean if there were news that would put President Bush in a bad light. ABC News commendably told its reporters to stop wearing flags and ribbons, lest an international audience mistake $\mathrm{ABC}$ for a government shill. ABC spokesman Jeffrey Schneider explained:

Especially in a time of national crisis, the most patriotic thing journalists can do is to remain as objective as possible. That does not mean journalists are not patriots. All of us are at a time like this. But we cannot signal how we feel about a cause, even a justified and just cause, through some sort of outward symbol. ${ }^{15}$

Reporters, like everyone else, have First Amendment rights to speak their opinions, and news outlet owners have the right to use their stations to express

14. Jim Rutenberg \& Bill Carter, Network Coverage a Target of Fire from Conservatives, N.Y. Times, Nov. 7, 2001, at B2.

15. Howard Kurtz, Peter Jennings, In the News for What He Didn't Say, WASH. Post, Sept. 24, 2001, at C1. 
theirs. But when this is done at the cost of at least the appearance of objectivity, the public loses a source of information that we can feel is reliable and complete. The freedom of the press guaranteed in the First Amendment is not so much the rights of writers and publishers as it is of the readers (the freedom of speech would be enough to protect the writers and publishers). The government hasn't restricted the freedom of the press, but the reporters, publishers, and station owners have, and although there is no redress against them under the First Amendment, the net effect upon the public is the same.

In choosing "patriotism over neutrality," news media may be reacting to their audiences' and advertisers' preferences, they may believe they are protecting a frightened public from panic, or they may be expressing their own feelings. If the reason is that they believe it is un-American to report anything that could raise questions about the Administration's handling of the crisis, the concern is misplaced. As Marquette University journalism professor Philip Seib points out, "raising difficult, unsettling issues is at the heart of journalism's role in a democracy. Doing that job provides the public with the tools it needs when deciding who should govern. For the news media, this is the highest form of patriotism." ${ }^{16}$ No matter what the reason, though, the choice amounts to bias over objectivity, particularly because newspapers and television news shows typically reserve space or time for opinion pieces through which they can get their own message across without compromising the objectivity, real or apparent, of their news reporting.

Private owners of news outlets are certainly free-they're guaranteed that freedom by the First Amendment, in fact-to choose propaganda over objectivity. They can go all the way and become "The Unofficial, Voluntary Mouthpiece of the U.S. Government" or "The Al Qaeda Apologists News Network" if they feel that strongly, or if they believe there is a greater audience for such things than for unbiased reporting. But the public will be the loser. As the existence of the Free Press Clause in the First Amendment demonstrates, the public needs unbiased news reporting, and it is important that some news shows and papers voluntarily provide that. Luckily, at least so far, they do.

\section{B. Threats to Free Speech}

The right to freedom of speech—like freedom of the press, a right important to listeners as well as to speakers-is also under attack, but not so much by the government. A few of the early statements from Administration officials were alarming but didn't seem to have "teeth." White House Press Secretary Ari Fleischer responded to Bill Maher's comments on Politically Incorrect by saying, "It's a terrible thing to say, and it's unfortunate. ... There are reminders to all Americans that they need to watch what they say, watch what they do, and this is not a time for remarks like that; there never is." ${ }^{17}$ Attorney General John

16. Good Journalism is Patriotic, MiLWAUKEE Journal-SENTINEL, Nov. 11, 2001, at J3.

17. J.R. Labbe, It's Tough to Squash the Press, but Someone's Always Trying, FT. WorTH STARTELEGRAM, Sept. 30, 2001, at 4. In a written transcript of Mr. Fleischer's remarks released the next 
Ashcroft testified before the Senate Judiciary Committee that the "tactics" of critics "who scare peace-loving people with phantoms of lost liberty ... only aid terrorists, for they erode our national unity and diminish our resolve. They give ammunition to America's enemies." ${ }^{18}$ Ashcroft's testimony was met with outrage and derision, ${ }^{19}$ and he issued a "clarification" shortly thereafter. Fleischer's and Ashcroft's statements were deplorable, but they do not seem to have been especially effective in chilling speech—to the contrary, they aroused widespread and vehement response. An editorial in The Washington Post noted:

It is the attorney general's function, or should be, to ensure that a lively debate over policy is protected ... [questioning policy] is not disloyal-in fact, it is a form of patriotism. ... Mr. Ashcroft may not like the criticism. But his job is to defend dissent, not to use the moral authority of his office to discourage people from participating in one of the most fundamental obligations of citizenship.

There have also been reports of public school students and teachers being disciplined for speaking out for or against U.S. response to the attacks, but there has been no concerted government effort toward prior restraint. More alarming are reports of FBI surveillance of and intrusion upon arts organizations and others, but so far these incidents have been rare. ${ }^{21}$ Similarly, the chilling effect inherent in the Patriot Act's overbroad surveillance powers over e-mail and domestic organizations will require our vigilance to ensure that they do not bear the bitter fruit that they potentially could. Also potentially dangerous is the Patriot Act's expansion of the Foreign Intelligence Surveillance Act to give the federal government broadened power to demand records, possibly including library and bookstore records; here, again, there has not-so farbeen any indication of abuse, but rather of consistent monitoring by booksellers and librarians (fortunately, both traditionally excellent First Amendment watchdogs). The various proposals cropping up to require public school students to recite the Pledge of Allegiance or pray or to enact an anti-flag-burning amendment to the Constitution can be considered government action once they are introduced as legislation, but even they are probably less a response to the September attacks than simply an attempt to ram through Congress measures that have repeatedly been held unconstitutional, seizing upon the possibility that opponents' resolve might be weakened by patriotic fervor, fear of criticism, or merely distraction by more urgent concerns.

Private parties, by contrast, have not been so restrained in stifling expression of unpopular opinion. Although balanced coverage does not mean equal time for opposing but noncredible speakers, news outlets have the responsibility

day by the White House, the "watch what they say" language had vanished. Labbe comments, "Just great. This administration finally realizes that words are important and demonstrates it by erasing some of them." Id.

18. Ashcroft: Critics of New Terror Measures Undermine Effort, Dec. 7, 2001, at http://www.cnn. com/2001/US/12/06/inv.ashcroft.hearing.index.html.

19. Editorial, John Ashcroft Misses the Point, N.Y. TIMES, Dec. 7, 2001, at A30.

20. Editorial, The Ashcroft Smear, WASH. Post, Dec. 7, 2001, at A40.

21. Matthew Rothschild, The New McCarthyism, THE PROGRESSIVE, Jan. 2002, available at www. progressive.org/0901/roth0102.html. 
to provide diverse opinions on controversial and complex subjects. Yet, since September 11, television news and talk shows have presented few guests opposed to war. ${ }^{22}$ Interestingly, the shows that have presented antiwar activists tend to be conservative talk shows, probably because they believe their audience will enjoy seeing the hosts bait liberals. Many of the major networks' executives either claim that they are having trouble finding credible antiwar guests - a dubious assertion even considering the breadth of popular support for the military response-or, more likely and more alarmingly, they fear their viewers will consider an attempt to present their views as unpatriotic. When $\mathrm{ABC}$ presented a segment on opposition to the war, host Ted Koppel gave a long introduction practically apologizing to viewers and reminding them, "You don't have to listen." ${ }^{23}$ CNN presented a panel of antiwar speakers, but showed each with an opposing guest in a split-screen format. ${ }^{24}$ They didn't even do that to Osama bin Laden.

Conservatives as well as liberals treasure freedom of speech; both, however, are guilty of trampling it through social pressure. Critics of American policy, including Michael Moore and Susan Sontag, were described as "traitors" by conservative columnist Bob Weir, who added:

I'm not in the mood to be patient with those who shake the Constitution in my face as a shield against my visceral emotions.... Someone who criticizes his own country, while body parts are still being pulled from the smoldering wreckage of two merciless attacks on his own people, is certainly not a friend. ${ }^{25}$

Harvard Law School Professor Alan Dershowitz wondered whether, in times of emergency, it would be desirable and constitutionally permissible for courts to have the power to issue warrants permitting interrogation methods classified as "torture." Although in his speech Dershowitz discussed giving judges the power to issue warrants in limited circumstances, his message apparently was not the endorsement of the use of torture but that "there must be a national debate about the circumstances in which torture is permissible and who should have the power to decide when to use it." ${ }^{26}$ Nevertheless, Dershowitz was immediately met with calls for everything from his expulsion from the American Civil Liberties Union to his being the first candidate for torture.

Despite the flood of reminders that American Muslims and ArabAmericans are loyal Americans, not per se suspects, and not to be discriminated against, a few people wondered publicly whether excessive caution against discrimination could hinder attempts to prevent more terrorist attacks, and whether Muslim-Americans and anti war activists might be more likely than

22. See, e.g., Alessandra Stanley, Opponents of the War are Scarce on Television, N.Y. TIMES, Nov. 9,2001 , at B4.

23. $I d$.

24. $I d$.

25. Bob Weir, America's Foolish Fifth Column, TEX. MERCURY, Vol. 1, Issue 4 (2001), available at http://www.thetexasmercury.com/articles/weir/WH20010923.html.

26. Tina Hesman, U.S. Now Might Have to Consider What Once was Unthinkable, Dershowitz Says, ST. LOUIS POST-DisPatCH, Nov. 5, 2001, at B6. 
others to be disloyal and to sympathize with and even aid the terrorists. ${ }^{27}$ Others wondered why some Muslim nations and organizations seemed to be slow in condemning terrorism, especially after reports of pro-bin Laden demonstrations in Arab and Muslim countries at which people rejoiced in the September 11 attack. None of these questions appeared to be an excuse to engage in discrimination against Arabs or Muslims. But the response was cries of racism and accusations that the speakers were advocating internment camps. ${ }^{28}$

The issue is not whether torture is ever acceptable or whether there is a "fifth column" in the United States. The most vehement responses were not counterarguments to comments on those subjects, but attacks on the people who made them for daring even to think about such things. More speech is always the best remedy for hated speech, but that's not what's going on here. The very act of wondering about something is being punished.

In fact, occasionally wondering about universally accepted ideas and values is a good way to keep them fresh and to reinforce, not undercut, our commitment to them. But even if wondering becomes questioning, challenging, or disagreement, this is precisely what the First Amendment is meant to protect from government interference. The damage to inquiry, dialogue, and thought is no less serious when it comes from private parties.

A few other incidents, including the postponement and "deglitzing" of the Emmy Awards broadcast, ${ }^{29}$ and the editing of movies and television shows shot before September 11 to remove images of the World Trade Center ${ }^{30}$ are much less worrisome - arguably not important at all. They aren't entirely insignificant, however, because they added, if only in small measure, to the public's coming to accept that there are now new rules for what can be shown and said to us and to the idea that shutting up is a patriotic gesture.

\section{Threats to Freedom of Religion}

Any fears that the United States government would shut down mosques and temples or interfere with their operations were quickly set to rest. There have been scattered attacks on mosques by private individuals, ${ }^{31}$ but police have responded appropriately, and government officials and community leaders across the board immediately condemned the violence.

In this area, there does not seem to be a wave of repression flowing from private sources. In fact, Americans are buying books about Islam in unprece-

27. See, e.g., John Podhoretz, The Fifth Column, N.Y. Post, Sept. 20, 2001, at 39.

28. See, e.g.,, Ben Fritz \& Brendan Nyhan, Bash the Arabs and Clobber the Left, AM. PROSPECT Sept. 28, 2001, at A1 available at http://www.prospect.org/webfeatures/2001/09/fritz-b-09-28.html.

29. “West Wing” Edges "Sopranos" on Emmy Night, November 5, 2001, at http://www.cnn.com/ SPECIALS/2001/stories/awards.night.

30. Peter Marks, A Nation Challenged: An Altered Image; The Manhattan Skyline's "Phantom Limb”, N.Y. TIMES, Oct. 24, 2001, at A1.

31. See, e.g., Police Seek Suspects in Islamic Center Vandalism, COLumbus DisPATCH, Feb. 4, 2002 , at $5 \mathrm{C}$. 
dented numbers. ${ }^{32}$ Whatever the readers' motivation, the general increase in knowledge about Islam and Muslims can be expected to lead to more, not less, understanding of and respect for Islam and its practice in America.

\section{Threats to Separation of Church and State}

The wall between church and state has been crumbling anyway, and the current climate certainly won't help reverse that trend. In this area, unlike speech, press, and free exercise of religion, we have not seen a vivid contrast between government restraint and public pressure. The reason is that the line between public and private action tends to blur in the Establishment Clause context, because the Establishment Clause, unlike the other First Amendment guarantees, which prohibit government interference with exercise of rights by individuals, is about limiting a particular category of government action, whether or not any private person or entity is directly affected.

The risk to freedom from state imposition or endorsement of religion often takes the form of an attempt to change statutory law or to amend the federal or a state constitution. Whether private support follows the political initiative or vice-versa, there will not be one without the other, or else the whole effort will fizzle quickly.

The most common area of concern is proposals to reintroduce prayer into public schools and other public arenas (ironically, exactly the sort of thing that the Taliban would endorse). The connection to the September 11 attacks is actually rather tenuous, and it takes two forms. The first and simplest is the rather cynical use of crisis as a smoke screen to try yet again to push through measures that have been held, time and again, to be unconstitutional. Nothing about the terrorist attacks or the situation afterward changes anything at all about the unconstitutionality of official prayers in public schools and other public settings. But protests seem mean-spirited, partisan, and petty when so many have died and soldiers are being placed at risk. Besides, the public has been too distracted by anthrax and other exotic threats to care much about the niceties of the Bill of Rights.

The second link to the terrorist attacks is more subtle: the confusion of patriotic sentiment with religious (specifically, Christian) sentiment and symbols. This is not just because of the suspected connection between the terrorists and an extreme type of Islam, which could transform the predictable "us versus them" emotional reaction to an attack that takes the shape of "Christian versus Muslim." In fact, the public seems to have accepted a more "medievalist/extremist/fundamentalist versus democratic/Western/secularist" model. ${ }^{33}$ Rather, it is because the urge to form a common identity during a frightening time, from which so much good arises, also can easily lead members of the Christian majority to identify their symbols and values as authentically and gen-

32. Alain Salles, The Arts in a Time of Crisis: What the World is Reading, WORLD PRESS REV., Dec. 2001. 
erally "American" symbols and values (recall the Lord's Prayer being recited right along with the Pledge of Allegiance in many American schools a generation ago, or even the recent gradual morphing of "Christmas" into "The Holiday Season," although no other religion has its major holidays in December). When that happens, some members of the majority, who now see their particular religious symbols as generally American and somehow patriotic, can have a very hard time understanding why all Americans wouldn't want to embrace them during a crisis, and may become suspicious of those who do not. It was no coincidence that "In God We Trust" was officially adopted as the national motto, and the words "under God" were added to the Pledge of Allegiance during the Cold War years - not due to some general rise in religious sentiment, but to distinguish Americans from "Those Godless Communists."

\section{E. Are First Amendment Rights Really More Important During War Time?}

It feels natural to proclaim, in the face of threats to First Amendment freedoms in the name of crisis, that those freedoms are even more important during time of crisis. It is certainly true that First Amendment freedoms, like civil liberties generally, are more likely to be limited during war time. But is it really true that our freedoms of speech, press, and religion are of more importance right now?

That question isn't as simple as it seems, but the answer is yes, they are, particularly with regard to speech and press. The free availability of a wide range of opinions and easy access to trustworthy and unbiased news sources is essential anytime for citizens in a democracy to evaluate the actions and decisions of their elected leaders and to hold those leaders accountable. The necessity for these "information freedoms" isn't greater during a time of crisis, but the stakes are higher. We must rely on each other's ability and willingness to stay informed and to catch both improper conduct and errors in judgment, more than ever when a wrong decision can mean disaster.

There is a fear that when the public has too much information (whatever that would be) on a frightening topic, panic can ensue-maybe not the sort that leads to people being trampled in the streets, but at least enough to damage consumer confidence and hurt the already suffering economy. But the vacuum left by withheld information quickly becomes filled with misinformation and rumors that are usually more alarming than the facts. Furthermore, Americans have made it clear that we prefer to have full information and that we do better when we have it. The Bush Administration, giving only vague information about the anthrax threat when it first surfaced, quickly reversed its policy after widespread criticism. After that, the Administration not only provided information to the public, it actually asked for the public's assistance in finding the source of the spores. ${ }^{34}$

34. Tom Brune, Feds Seek Public's Help as They Show Pictures of Suspects, NEWSDAY (New York), Sept. 28, 2001, at A3. 
Perhaps the greatest reason for the heightened importance of the First Amendment during a crisis, though, is the unfortunate reality that, even when the nation most needs unselfish and nonpartisan devotion from its leaders, there are some who will take advantage of the situation to push through their own agendas-political or, worse, personal and even illegal. It is hard to believe, for example, even from a conservative perspective, that the "economic stimulus" measures consisting of handouts to energy and mining interests, mostly in Texas, who gave large contributions to the Republican party last year, really are necessary to stimulate the economy, let alone are somehow justified by the September 11 attacks. ${ }^{35}$ More likely, profiteers hope that our attention is sufficiently diverted by riveting war and terrorism news to allow them to sneak under the radar money grabs that would cause an uproar in the press and on the street at any other time. The public's and media's ability to perform their important watchdog functions are threatened not only by government censorship, but also by private accusations of disloyalty leveled, in the name of national emergency, at anyone who criticizes or even questions government actions.

\section{II}

\section{We HAVE MET THE ENEMY AND HE IS Us ${ }^{36}$}

The government, at every level, thus far has refrained from infringing upon our freedoms of speech, press, assembly, and religion as dreadfully as it could have, and definitely not at the level feared immediately after the attacks. There have been no mosque closures, no news censors, no House Un-American Activities Committee.

But the point here is not whether or not the government has gone too far in limiting First Amendment rights. You don't have to be an ultra-sensitive civil liberties zealot to see that the danger is there, regardless whether the government is the culprit. The tyranny of the majority can, and will, express itself through private pressures, limits, and punishments, free of any constitutional limitation. The Red Scare of the Forties and Fifties ruined lives not only through Senator McCarthy's committee, but also through the blacklisting of private industries and organizations.

We cannot count on the First Amendment to help us with that. So we must count on ourselves. In a time when emotions can outrun not only our common sense, but also our most precious values, we must be vigilant with each other and with ourselves. After all, holding our government to its own high standards is a compliment, not a threat. Wanting to know what our leaders and public servants are doing and asking questions is not disloyal; it's patriotic. Taking it upon oneself to protect the Constitution is not treason; it is an act of great civic responsibility. And making sure that dissenting opinions are aired is about as American as you can get.

35. Paul Krugman, The One-Eyed Man, N.Y. Times, Oct. 31, 2001, at A15.

36. Walt Kelly, Pogo: We Have Met the Enemy And He Is Us (1972). 
This crisis, like all others before it, eventually will pass. In the meantime, we must not become our own House Un-American Activities Committee. If we do, we will live to regret it, because we, too, will surely become its victims. 